\title{
The M1 Muscarinic Agonist Cl-1017 Facilitates Trace Eyeblink Conditioning in Aging Rabbits and Increases the Excitability of CA1 Pyramidal Neurons
}

\author{
Craig Weiss, ${ }^{1}$ Alison R. Preston, ${ }^{1}$ M. Matthew Oh, ${ }^{1}$ Roy D. Schwarz, ${ }^{2}$ Devin Welty, ${ }^{2}$ and John F. Disterhoft ${ }^{1}$ \\ ${ }^{1}$ Department of Cell and Molecular Biology, Northwestern University Medical School, Chicago, Illinois 60611, and \\ 2Parke-Davis Pharmaceutical Research, Ann Arbor, Michigan 48105
}

\begin{abstract}
The M1 muscarinic agonist $\mathrm{Cl}-1017$ was administered intravenously to aging rabbits on a daily basis before and during hippocampally dependent trace eyeblink conditioning sessions. Circulating levels of $\mathrm{Cl}-1017$ were significantly related to the drug dose. The drug was found to significantly increase the rate and amount of learning in a dose-dependent manner with no significant effects on the amplitude, area, or latency of conditioned responses. There was no evidence of pseudoconditioning at the highest drug concentration, and the minimally effective dose produced only mild and temporary hypersalivation as a side effect. $\mathrm{Cl}-1017(10 \mu \mathrm{M})$ was also found to increase the excitability of CA1 pyramidal neurons recorded from hip-
\end{abstract}

pocampal slices from young and aging naive rabbits as measured by changes in spike-frequency adaptation and the postburst afterhyperpolarization. These biophysical changes were reversed with either atropine $(1 \mu \mathrm{M})$ or pirenzepine $(1 \mu \mathrm{M})$. These results suggest that $\mathrm{M} 1$ agonists ameliorate age-related learning and memory impairments at least in part by reducing the afterhyperpolarization and spike-frequency adaptation of hippocampal pyramidal neurons and that M1 agonists may be an effective therapy for reducing the cognitive deficits that accompany normal aging and/or Alzheimer's disease.

Key words: acetylcholine; afterhyperpolarization; Alzheimer's disease; cholinesterase; hippocampus; learning
Alzheimer's disease (AD) is partially characterized by a loss of forebrain cholinergic neurons and depletion of cortical cholinergic axons (Perry et al., 1978; Bartus et al., 1982; Whitehouse et al., 1982; Whitehouse and Au, 1986; Geula and Mesulam, 1994; Levey, 1996; Robinson and Harrell, 1997). These data suggest that therapies based on cholinergic pharmacology might be successful at ameliorating behavioral consequences of AD (Schwarz et al., 1997). Drugs currently used to treat AD (Tacrine and Donepezil) inhibit cholinesterases and rely on the presence of cholinergic neurons, which gradually die as the disease progresses. A therapy based on agonist replacement may be more successful in the long term because muscarinic acetylcholine receptors from postmortem AD brains appear to remain intact (Mash et al., 1985; Pearce and Potter, 1991), although some may be functionally disabled (Ferrari-DiLeo et al., 1995; Flynn et al., 1995).

Successful therapies would be based on receptor activation for the afferents that are affected by the disease, i.e., the pharmacologically identified M1 receptor (Hulme et al., 1990) and the genetically identified $\mathrm{m} 1$ receptor (Bonner et al., 1987). The highest concentration of M1 receptors is in the dentate gyrus (Messer and Hoss, 1987), and the $\mathrm{m} 1$ receptor is highly concentrated in cortex, hippocampus, and striatum. All five receptor

Received Feb. 4, 1999; revised Oct. 21, 1999; accepted Oct. 21, 1999.

This work was supported by Parke-Davis Pharmaceutical Research and National Institutes of Health Grants R37 AG08796 and 1F31 MH11737. We thank Sarah Gardiner, Mark Crowe (Access Technologies), Elke Lipka, Karen Boszor, and Matthew Weiss.

Correspondence should be addressed to Dr. Craig Weiss, Department of Cell and Molecular Biology, W129, Searle Building, Room 4-445, Northwestern University Medical School, Chicago, IL 60611. E-mail: cweiss@nwu.edu.

A.R.P.'s present address: Department of Psychology, Stanford University, Stanford, CA 94305.

Copyright $\odot 2000$ Society for Neuroscience $0270-6474 / 00 / 200783-08 \$ 15.00 / 0$ types (m1-m5) are coupled to G-proteins, and $\mathrm{m} 1, \mathrm{~m} 3$, and $\mathrm{m} 5$ receptors activate phospholipase $\mathrm{C}$, which in turn activates diacylglycerase, $\mathrm{IP}_{3}$, and protein kinase $\mathrm{C}$. This sequence of events is often associated with increased neural plasticity, including acquisition of trace eyeblink conditioning (EBC) in the rabbit (Van der Zee et al., 1997). Furthermore, scopolamine (a muscarinic antagonist) disrupts trace EBC (Kaneko and Thompson, 1997), and the M1 antagonist pirenzepine disrupts other learning paradigms (Caufield et al., 1983; Hagan et al., 1987; Messer et al., 1987; Bymaster et al., 1993; Ohno et al., 1994).

CI-1017 is a second generation agonist designed to selectively activate the M1 receptor while minimizing peripheral side effects (Tecle et al., 1998). It is an oxime of 1-azabicyclo[2.2.1] heptan3-one with a 3-phenylpropargyl analog substituent, and it is identified as a relatively $\mathrm{m} 1$-selective partial agonist by cell metabolism, cell amplification, and second messenger assays with an overall selectivity of $\mathrm{m} 1 \geq \mathrm{m} 4>\mathrm{m} 3=\mathrm{m} 5 \gg \mathrm{m} 2$ (Jaen et al., 1995).

The aim of this study was to determine whether CI-1017 would significantly improve the learning rate of aging rabbits during trace EBC. This is an interesting task to examine because it is hippocampally dependent in rabbits (Solomon et al., 1986; Moyer et al., 1990; Kim et al., 1995) and humans (Disterhoft et al., 1996a; McGlinchey-Berroth et al., 1997), and it is significantly impaired by aging (Disterhoft et al., 1995; Thompson et al., 1996a) and AD (Woodruff-Pak et al., 1990; Solomon et al., 1991, 1995; Woodruff-Pak and Papka, 1996). Improved acquisition of EBC by aging rabbits (Kronforst-Collins et al., 1997), with concomitant enhancement of neuronal excitability (Oh et al., 1999), was demonstrated previously with the cholinesterase inhibitor metrifonate. We now demonstrate both facilitation of EBC and increased hippocampal CA1 pyramidal neuron excitability with the muscarinic agonist CI-1017. 


\section{MATERIALS AND METHODS}

Subjects and surgery. Subjects in the behavioral pharmacology experiment were 26 New Zealand White female rabbits that were 30 or 36 months of age at the start of the experiment. Surgery to implant a femoral catheter, vascular access port, and atraumatic head restraint was done using sterile procedures approved by the Northwestern University Animal Care and Use Committee. Rabbits were anesthetized with ketamine $(45 \mathrm{mg} / \mathrm{kg})$ and xylazine $(7.5 \mathrm{mg} / \mathrm{kg})$, and the scalp, back, and groin were shaved and cleaned with alcohol and betadine. A midline incision was made along the back, and a pocket was formed by cutting any subdermal adhesions. A vascular access port (GPV-4S-24 or TI200-4S; Access Technologies, Skokie, IL) was filled with heparinized saline, placed within the pocket, and sutured in place to the underlying muscle. An incision was also made inside the groin, and a long forceps was used to tunnel under the skin and lead the catheter attached to the vascular access port (venaport) to the femoral region. The wound for the venaport was cleaned with betadine and sutured shut with $4-0$ nylon. The femoral vein was exposed, cleared of adhering tissue, and punctured with a catheter introducer (\#6999; Becton Dickinson, Franklin Lakes, NJ). The catheter was inserted into the vein, advanced $\sim 10 \mathrm{~cm}$, and sutured into place with silk stays and 4-0 nylon. The wound was then cleaned and closed with 4-0 nylon.

The rabbit was placed within a stereotaxic device to restrain the head. The scalp was cleaned, and a midline incision was made to expose bregma and lambda. The periosteum was scraped away, the skull was cleaned with betadine and hydrogen peroxide, and four holes were made to receive self-tapping stainless steel screws. The screws and skull were covered with dental acrylic, and a restraining device containing four nylon bolts $(6-32 \times 3 / 4$ inch $)$ was placed within the cement. The wound was then cleaned, and the rabbit was placed on a warming pad to recover. The rabbit was given Buprenex $(0.4 \mathrm{mg} / \mathrm{kg})$ for analgesia when it was ambulatory, and it was returned to its home cage.

The venaport in each rabbit was injected daily with $0.3 \mathrm{ml}$ of heparinized saline to keep the port and catheter patent. Rabbits were given a minimum recovery time of 1 week and were then brought to the laboratory for daily eyeblink conditioning sessions. Rabbits were placed within a cloth bag that was tied at the neck and tail, placed within a Plexiglas box that had a yoke surrounding the neck, and the lids of the right eye were held open with dress hooks and Velcro (Disterhoft et al., 1977). The rabbit was placed within a sound attenuating chamber, the nylon restraining bolts were fastened to a rigid support, and an infrared reflective sensor and air puff delivery tube were placed in front of the right eye (Thompson et al., 1994). The rabbits were habituated to the restraining device and conditioning chamber for $2-5 \mathrm{~d}$ daily before receiving any conditioning stimuli.

Drug delivery. Rabbits received CI-1017 (which was provided by ParkeDavis, Ann Arbor, MI) or vehicle (0.9\% saline) as of the first day of conditioning. The rabbits were randomly divided into four groups of 5.0, $1.0,0.5$, and $0.0 \mathrm{mg} / \mathrm{ml}$, and the experimenter was blinded to the dose. The rabbits had a mean weight of $4.15 \mathrm{~kg}$ (range of 3.2-4.7 kg). Each rabbit was given $0.6 \mathrm{ml}$ of the drug over the course of $1 \mathrm{~min}(0.3 \mathrm{ml}$ to flush the catheter of heparinized saline and a bolus of $0.3 \mathrm{ml}$ to raise the plasma level of the drug quickly) and then inf used with the drug at a rate of $2.7 \mathrm{ml} / \mathrm{hr}$. Conditioning trials began $30 \mathrm{~min}$ after the start of the infusion, and the infusion continued for the duration of each daily session. The nominal loading dose was thus $0.361,0.072,0.036$, or 0.0 $\mathrm{mg} / \mathrm{kg}$, and the nominal maintenance dose was $3.25,0.65,0.325$, or 0.0 $\mathrm{mg} \cdot \mathrm{kg}^{-1} \cdot \mathrm{hr}^{-1}$.

Blood sampling. Blood samples were taken from the marginal ear vein of all rabbits immediately after training on training day 10 . The samples were mixed with heparin and centrifuged at $3000 \mathrm{rpm}$ for $5 \mathrm{~min}$ at $4^{\circ} \mathrm{C}$. The plasma was then removed and stored at $-80^{\circ} \mathrm{C}$ until it was analyzed for circulating levels of CI-1017.

Behavioral training. The conditioning task involved pairing a tone $(100$ msec, $6 \mathrm{kHz}, 90 \mathrm{~dB}, 5 \mathrm{msec}$ rise-fall time) with an air puff to the eye (150 $\mathrm{msec}, 3 \mathrm{psi})$. A $500 \mathrm{msec}$ stimulus-free trace period separated the tone and air puff to make the task dependent on the hippocampus (Moyer et al., 1990). A computer controlled delivery of the stimuli and recording of the behavior (Akase et al., 1994). This frequency of the conditioning stimulus (CS) is optimal for the rabbit auditory system (Martin et al., 1980) and was delivered by headphones to the ear canal via rubber tubing. The unconditioned stimulus (US) was an air puff that was adequate to evoke extension of the nictitating membrane (NM). The air puff was supplied by compressed air and controlled by a regulator and solenoid valve. Movement of the NM was transduced by an infrared sensor, which converts a change in reflectance from the cornea to a change in voltage (Thompson et al., 1994).

Training sessions were conducted while the rabbits were restrained in a cloth bag and Plexiglas box. They received one session per day with each session consisting of 80 presentations of the paired stimuli. Trials were separated by a random intertrial interval (ITI) of 30-60 sec. Conditioned responses (CRs) were defined as extensions of the NM that exceeded the mean baseline amplitude by 4 SDs for a minimum of 10 msec. Most rabbits were conditioned with the trace conditioning paradigm for $15 \mathrm{~d}$ ( 3 weeks of $5 \mathrm{~d}$ ) and then with delay conditioning ( $750 \mathrm{msec}$ tone, $150 \mathrm{msec}$ coterminating air puff) for $5 \mathrm{~d}$. Some rabbits were trained for $20 \mathrm{~d}$ with trace conditioning and $5 \mathrm{~d}$ with delay conditioning. All rabbits were given a sixth day of delay conditioning with attenuated tones to detect their sensitivity to the CS.

Behavioral control sessions $(n=15)$ were given to an additional 12 rabbits (six with vehicle and six with $5.0 \mathrm{mg} / \mathrm{ml}$ ) to test for pseudoconditioning and sensitization. These sessions consisted of 80 trials with tones and 80 trials with air puffs. The two types of trials were presented in random order with a $15-30 \mathrm{sec}$ ITI. These rabbits were then switched to the delay paradigm for five daily sessions.

Behavioral data analysis. The data were analyzed with ANOVA that used drug dose as a group variable and daily scores as a repeated measure. These scores included the percent of trials with CRs, the peak amplitude of CRs, the area of CRs (the sum of the amplitudes for each sample during the CS-US period), the latency to the peak of the CR, and the average amplitude of the unconditioned response (UR). Post hoc tests of significance $(p \leq 0.05)$ were performed using Fisher's least significance difference test. Analyses were performed using StatVIEW 4.1 (SAS Institute, Cary, NC) on a Macintosh PowerPC computer (Apple Computers, Cupertino, CA).

Biophysical recordings. The effects of CI-1017 on the biophysical properties of CA1 pyramidal neurons from hippocampal slices from six young (2-3 months) and seven aging (31-38 months) naive rabbits were examined. The tissue preparation and current-clamp intracellular recording techniques have been described previously (Oh et al., 1999). Briefly, rabbits were deeply anesthetized with halothane, and the brain was extracted within $1 \mathrm{~min}$ of death. Hippocampal slices $(300 \mu \mathrm{m})$ were made using a vibratome and then placed in a holding chamber at room temperature $\left(22^{\circ} \mathrm{C}\right)$ for at least $45 \mathrm{~min}$ before being transferred to the submersion chamber (Harvard Apparatus, Holliston, MA) for recording.

Biophysical measurements [postburst afterhyperpolarization (AHP), spike-frequency adaptation (accommodation), input resistance, and resting membrane potential] were recorded. A burst of four action potentials was used to examine the AHP, and an $800 \mathrm{msec}$ pulse at the same current was used to examine accommodation. CA1 neurons were included in the study if the neurons had little spontaneous activity at rest, a stable resting membrane potential less than $-60 \mathrm{mV}$, an action potential duration $>1.2$ msec from rise threshold to recrossing the resting potential, an input resistance $>20 \mathrm{M} \Omega$, and an action potential amplitude $>80 \mathrm{mV}$ from rest. Biophysical properties were measured at least $5 \mathrm{~min}$ after the initial impalement. The neurons were held near $-70 \mathrm{mV}$ (using less than \pm 0.2 $\mathrm{nA}$ ) to ensure that any effects were not attributable to voltage-dependent membrane properties (Oh et al., 1999). The following sequence of biophysical recordings was used: (1) baseline measurements recorded in artificial CSF (aCSF); (2) measurements in aCSF containing $10 \mu \mathrm{M}$ CI-1017; and (3) measurements in aCSF containing $10 \mu \mathrm{M}$ CI-1017 and either $1 \mu \mathrm{M}$ atropine (to test for reversal of a cholinergic effect; Sigma, St. Louis, MO) or $1 \mu \mathrm{M}$ pirenzepine (a specific M1 antagonist; Sigma). The neurons were allowed to stabilize for $10 \mathrm{~min}$ at $-75 \mathrm{mV}$ (or at rest if the membrane potential was less than $-75 \mathrm{mV}$ ) during each change in perfusate. Data from the biophysical measurements were analyzed with a repeated-measures ANOVA and Fisher's PLSD test. The mean \pm SE values of the measures are reported.

\section{RESULTS}

\section{Behavior}

The behavioral results are based on data from 23 conditioned rabbits and 12 control rabbits. There were three other conditioned rabbits that were excluded from the analyses: one did not exhibit any startle responses, indicating it was deaf, and two failed to show CRs even during simple delay conditioning, which suggested a generalized functional impairment including the cerebellum and associated brainstem circuitry. There were four, 


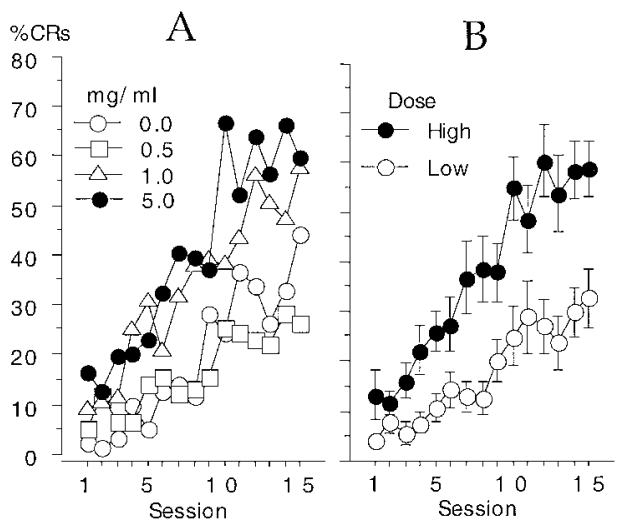

Figure 1. A, A graph of the percent of trials with CRs across 15 daily training sessions as a function of drug dose. $B$, The two higher doses $(5$ and $1 \mathrm{mg} / \mathrm{ml}$ ) exhibited significantly more CRs than the two lower doses $(0$ and $0.5 \mathrm{mg} / \mathrm{ml})$. Data are means \pm SE. Error bars are omitted from $A$ for clarity.

seven, five, and seven rabbits that completed at least $15 \mathrm{~d}$ of trace conditioning in the $0.0,0.5,1.0$, and $5.0 \mathrm{mg} / \mathrm{ml}$ groups, respectively. All 12 control rabbits completed the study and exhibited CRs after they were switched to a delay conditioning paradigm.

An ANOVA for the percent of trials with CRs during $15 \mathrm{~d}$ of conditioning indicated that there was a significant effect of dose $\left(F_{(3,19)}=4.92 ; p=0.011\right)$, a significant increase in CRs across days of training $\left(F_{(14,266)}=26.27 ; p<0.0001\right)$, and a significant interaction between the two factors $\left(F_{(42,266)}=1.78 ; p=0.004\right)$. A graph of these results is shown in Figure $1 A$. The $5.0 \mathrm{mg} / \mathrm{ml}$ group exhibited the greatest level of conditioning $(66.8 \pm 8.2 \%$ on day 10) and attained this level more quickly than the other groups attained their peak level of CRs. The vehicle control rabbits did not exhibit their maximum of $44 \pm 8.8 \%$ CRs until day 15 .

Post hoc tests indicated that the high-dose set (1.0 and 5.0 $\mathrm{mg} / \mathrm{ml}$ groups) exhibited significantly more CRs than the lowdose set $(0.0$ and $0.5 \mathrm{mg} / \mathrm{ml}$ groups), and there was no significant difference between each of the two groups within the high- or low-dose sets. Figure $1 B$ presents the increase in percent CRs as a function of high- or low-dose sets to show the effect of the drug more clearly. The interaction of dose and sessions appears to be due to the more rapid increase in the percent of trials with CRs for the high-dose set compared with the low-dose set. This increase persisted for the duration of the experiment so that the high-dose set consistently outperformed the low-dose set (Fig. $1 B)$. The two sets of rabbits were significantly different from each other on the first day of conditioning and on all subsequent days, except days 2 and 6.

Some of the rabbits (19 of 23) were conditioned for $20 \mathrm{~d}$ instead of $15 \mathrm{~d}$. An ANOVA for this group of rabbits produced the same set of significant results as presented above. The results also indicated that the performance of the $5.0 \mathrm{mg} / \mathrm{ml}$ group continued to improve beyond day 15 (day 19, $77.8 \pm 7.2 \% \mathrm{CRs}$ ), whereas the performance of the $1.0 \mathrm{mg} / \mathrm{ml}$ group plateaued between days 15 and 17 and then decreased to a level about that of day 10 (day 20, $46.6 \pm 11.2 \%$ CRs).

The CRs of the conditioned rabbits improved in quality, as well as in frequency of occurrence. An ANOVA for the peak amplitude of the CR (on trials in which there was a CR) indicated a significant increase in amplitude over the course of training $\left(F_{(14,266)}=2.64 ; p=0.001\right)$. There was no significant difference among the dose groups and no significant interaction of dose and
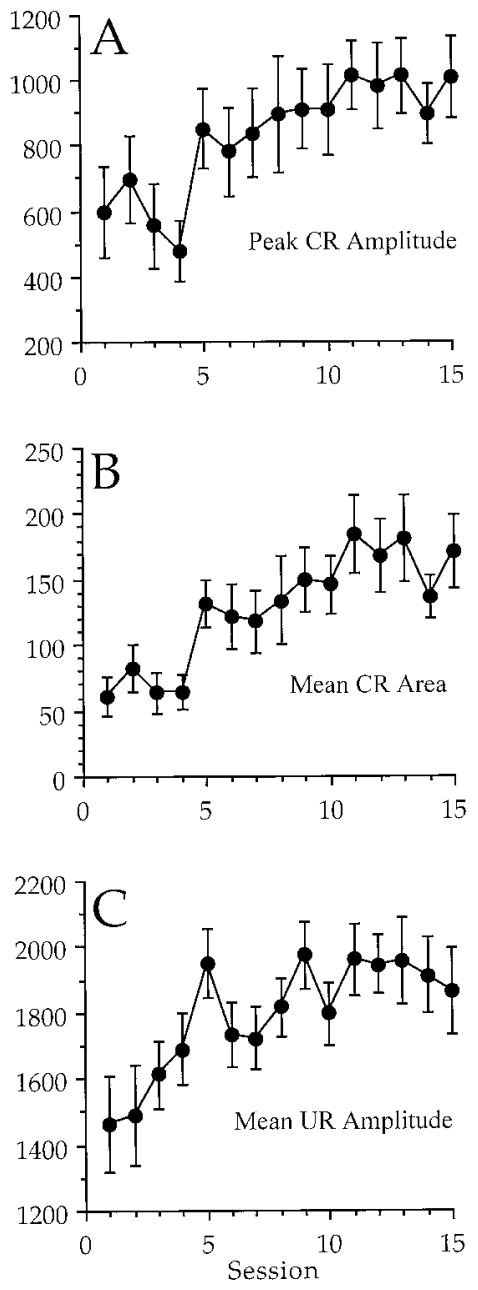

Figure 2. A, A graph of the peak amplitude of response during the CS-US period on trials in which there was a CR. B, A graph of the area of response during the CS-US interval on trials in which there was a CR. $C$, A graph of the mean amplitude of response during the UR period. There was a significant increase in all three measures across sessions, but no significant differences among the groups and no significant interaction of dose and session were found. A comparison of these data with those in Figure 1 indicate that the high-dose rabbits showed more CRs, rather than CRs with different characteristics. The $y$-axis is shown in integrated units.

session. A graph of the increase in the peak CR amplitude is shown in Figure $2 A$.

An ANOVA of the area of response on trials in which there was a CR indicated that there was a significant increase over the course of training $\left(F_{(14,266)}=4.12 ; p<0.001\right)$. There was no significant difference among the dose groups and no significant interaction of dose and session. A graph of the increase in the area of response is shown in Figure $2 B$.

An ANOVA of the latency to the peak of the response during the CS-US period on trials in which there was a CR indicated that there was a significant interaction of dose and session $\left(F_{(42,266)}=2.22 ; p<0.0001\right)$. The interaction was apparently caused by shorter latencies for the control group during the first three sessions $(170 \mathrm{msec})$. There were no significant main effects of dose or session. The mean latency to the peak of the CR during sessions 11-15 for all groups combined was $454.3 \mathrm{msec}$ (air puff onset was at $600 \mathrm{msec}$ ). There were no significant differences revealed by an ANOVA when the groups were combined into two groups of high and low dose. 


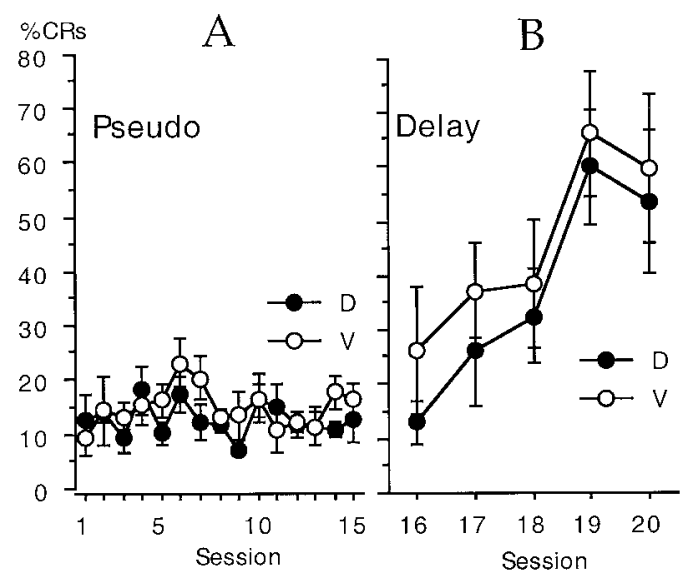

Figure 3. A, CI-1017 had no significant effect on the percent of trials with apparent CRs during 15 behavioral control sessions that presented unpaired tones and air puffs, i.e., there was no pseudoconditioning. $B$, CI-1017 had no significant effect on the rate of learning when the same rabbits were subsequently switched to the delay conditioning paradigm for five daily sessions. $D$, Drug at $5 \mathrm{mg} / \mathrm{ml} ; V$, vehicle control.

The UR was also examined for changes in amplitude. An ANOVA indicated that there was a significant increase in the mean amplitude of response across sessions during the UR period $\left(F_{(14,42)}=3.73 ; p<0.0001\right)$. This increase is shown in Figure $2 C$ and most likely reflects the presence of reflex facilitation and/or long-duration CRs that added to the UR (see Discussion). There was no significant effect of dose and no significant interaction of dose and session. In fact, there was no significant difference between the two dose sets on any day of conditioning, including the first day when there was the least chance of contamination by a CR. The UR was also examined on air puff alone trials (during the last day of training with attenuated tones) to avoid contamination by the CR. A $t$ test for the effect of the drug indicated no significant difference in the peak amplitude of the UR between the high- and low-dose sets (1409 \pm 223 integrated units vs $1834 \pm 130$ integrated units, respectively).

\section{Pseudoconditioning controls}

The possibility of pseudoconditioning or sensitization was examined among the behavioral control rabbits with an ANOVA using dose as a grouping variable and percent of trials with CRs on tone alone trials as a repeated measure. The results indicated that there was no significant change in percent CRs across training sessions, and there was no significant difference between rabbits that received either vehicle or the highest dose of CI-1017 (5 $\mathrm{mg} / \mathrm{ml})$. The behavioral control rabbits had a mean of $13.9 \pm$ $0.88 \%$ CRs for all rabbits combined. These results are shown in Figure $3 A$.

An ANOVA on the mean amplitude of the UR also failed to show either a significant difference between the drug and vehicle groups or a significant interaction between the group effect and days of training. There was a significant increase in the UR amplitude across days $\left(F_{(14,140)}=3.5\right)$, but this effect appeared to be due to the increase in UR amplitude from day 1 to day 2 . The effect was no longer significant when day 1 was excluded from the analysis.

The control rabbits were then switched to a delay conditioning paradigm for 5 training days by extending the duration of the CS until it coterminated with the US, i.e., a $750 \mathrm{msec}$ CS. An ANOVA of drug group by training session indicated that there was a significant increase in CRs across sessions $\left(F_{(4,40)}=9.0 ; p<\right.$ $0.0001)$ but no significant difference between the control and CI-1017 groups. These data are shown in Figure 3B. The largest difference between the groups occurred on the first day of delay training; the control rabbits had $26 \pm 12 \%$ CRs and the CI-1017 rabbits had $13 \pm 4 \% \mathrm{CRs}$. The mean maximum daily percent CRs was $59.8 \pm 13.8 \%$ for the control rabbits and $60.2 \pm 10.6 \%$ for the rabbits receiving $5 \mathrm{mg} / \mathrm{ml} \mathrm{CI-1017.}$

\section{Side effects}

Notable side effects of the drug were observed in the highest dose group $(5 \mathrm{mg} / \mathrm{ml})$. This group demonstrated considerable and persistent salivation, increased likelihood of defecation, and an increase in arousal to occasional noises in the laboratory. Salivation in the highest dose group prevented the experimenter from being completely blind to this dosing group. It was persistent during and across sessions and began soon after the loading bolus injection. The salivation effect was more variable in the $1.0 \mathrm{mg} / \mathrm{ml}$ group and nonexistent in the two lower dose groups. Defecation (which was apparently related to the training sessions) only occurred in rabbits on the highest dose $(5 \mathrm{mg} / \mathrm{kg})$. It was noted in four of seven rabbits on the first day, and it persisted throughout the experiment for two of the four rabbits.

Rabbits were examined for their auditory sensitivity on the last day of training (day 6 of delay conditioning) to systematically test for an increase in auditory-mediated arousal. They were given two sets of five trial blocks with paired presentations of the CS and US in which the tone was attenuated between 0 and $30 \mathrm{~dB}$ in $5 \mathrm{~dB}$ steps (two blocks of air puff alone trials were also given). Data from the rabbits that were originally trained with trace conditioning were analyzed with an ANOVA for the percent of trials with CRs by dose (high or low) and the amount of attenuation. The results indicate a significant effect of dose $\left(F_{(1,14)}=\right.$ $12.52 ; p=0.003)$ and attenuation $\left(F_{(6,84)}=20.04 ; p<0.0001\right)$ but no significant interaction. Rabbits in the high-dose set had significantly more CRs than those in the low-dose set just as they did during trace EBC training sessions. Both groups showed equivalent declines in responding as the CS amplitude was attenuated, as indicated by the lack of interaction in the ANOVA. The results for rabbits that started as behavioral controls for pseudoconditioning also indicate that the vehicle group had significantly fewer CRs than those receiving $5 \mathrm{mg} / \mathrm{ml}\left(F_{(1,10)}=7.7 ; p=0.02\right)$ and that both groups combined had a significant decline in percent CRs with increasing attenuation $\left(F_{(6,60)}=7.1 ; p<0.0001\right)$. There was no significant interaction of the drug and attenuation for this group of rabbits either. In fact, the rate of decline with increasing attenuation was quite similar between the high- and low-dose drug groups.

\section{Blood analysis for $\mathbf{C l - 1 0 1 7}$}

Approximately $1 \mathrm{ml}$ of blood was collected from the marginal ear vein immediately after the session on day 10 . The plasma was taken and analyzed for circulating levels of CI-1017. The results indicate a high correlation of delivery dose and plasma concentration of CI-1017 $\left(r^{2}=0.92\right)$ for the conditioned rabbits. Furthermore, an ANOVA indicated a significant effect of dose on plasma concentration $\left(F_{(3,19)}=100.1 ; p<0.0001\right)$ with the 5 $\mathrm{mg} / \mathrm{ml}$ dose having significantly greater levels of CI-1017 than the 1.0 and $0.5 \mathrm{mg} / \mathrm{ml}$ groups $(622 \pm 46$ vs $102 \pm 16$ and $58 \pm 7$ $\mathrm{ng} / \mathrm{ml})$. There were no significant differences among the other doses. The analysis also indicated that the behavioral control rabbits receiving $5 \mathrm{mg} / \mathrm{ml}$ had a mean of $623 \pm 79 \mathrm{ng} / \mathrm{ml}$. 
The day 10 plasma concentration of CI-1017 was then compared with the percent of trials with CRs on day 10 for the highand low-dose sets of conditioned rabbits. The results indicate that the low-dose set had a mean CI-1017 plasma level of $46.4 \pm 7.2$ $\mathrm{ng} / \mathrm{ml}$ and a mean of $25.1 \pm 5.8 \%$ CRs. The high-dose set of rabbits had a mean CI-1017 plasma level of $405.2 \pm 81.8 \mathrm{ng} / \mathrm{ml}$ and a mean of $54.9 \pm 6.4 \%$ CRs. A regression analysis of the combined data (high- and low-dose sets) indicated that the data could be fit with a second-order polynomial. That equation indicated a correlation coefficient of $0.69\left(r^{2}=0.48\right)$, a Y intercept of $20.0 \% \mathrm{CRs}$, and a peak effect that would occur at $67.4 \% \mathrm{CRs}$ and $595.3 \mathrm{ng} / \mathrm{ml}$.

\section{In vitro physiology}

The effects of CI-1017 were examined in eight CA1 hippocampal neurons from five young naive rabbits, and in 12 neurons from seven aging naive rabbits. A repeated-measures ANOVA (with post hoc PLSD tests) indicated that bath application of the drug $(10 \mu \mathrm{M})$ significantly reduced both the mean amplitude of the postburst AHP $\left(F_{(1,18)}=51.0 ; p<0.0001\right)$ and spike-frequency accommodation $\left(F_{(1,17)}=58.8 ; p<0.0001\right)$. The area $\left(F_{(1,18)}=\right.$ $32.3 ; p<0.0001)$ and duration $\left(F_{(1,18)}=42.4 ; p<0.0001\right)$ of the AHP were also significantly reduced by CI-1017 (data not shown). There was no significant effect of age on the AHP, in contrast with our previous reports (Moyer et al., 1992; Disterhoft et al., 1996b; Oh et al., 1999) apparently because of the small sample size in this study. There also was no significant interaction of age with application of the drug.

The effect of CI-1017 on the mean amplitude of the AHP and on accommodation is shown in Figure 4. These effects were reversed by the addition of the general muscarinic antagonist atropine ( $1 \mu \mathrm{M}$; in four young cells) or the specific M1 antagonist pirenzepine ( $1 \mu \mathrm{M}$; in nine aging cells). Fisher's PLSD test for the 13 cells combined revealed that the AHP ( $p=0.0003)$, accommodation $(p<0.0001)$, AHP area $(p=0.0005)$, and AHP duration $(p<0.0001)$ were all significantly reversed by the muscarinic antagonists. Examples of the effect of CI-1017 on a single hippocampal neuron are shown in Figure 5. Reversal of the effects by atropine indicates that CI-1017 acts primarily by enhancing the effect of muscarinic cholinergic neurotransmission.

\section{DISCUSSION}

The M1 agonist CI-1017 significantly increased the learning rate of aging rabbits during hippocampally dependent trace eyeblink conditioning. The increase was seen at an intravenous dose as low as $1.0 \mathrm{mg} / \mathrm{ml}$, and rabbits that received $5.0 \mathrm{mg} / \mathrm{ml}$ did not show significantly better learning than rabbits in the $1.0 \mathrm{mg} / \mathrm{ml}$ group (although the $5 \mathrm{mg} / \mathrm{ml}$ group reached their maximum more quickly than the $1 \mathrm{mg} / \mathrm{ml}$ group). The increase in the percentage of CRs for the two highest dose groups occurred without significant changes in the quality of the $\mathrm{CR}$, i.e., there was no significant effect of dose on amplitude, area, or latency of the conditioned response. These parameters did improve over the course of training sessions as rabbits acquired the task, but dose was not a significant factor, and there was no significant interaction of dose and session. Furthermore, there was no evidence of pseudoconditioning. Thus, these data suggest that CI-1017 acts on associative sites to increase the probability of evoking a CR and not on unconditioned reflex sites. These effects are similar to those observed in aging rabbits treated with the cholinesterase inhibitor metrifonate (Kronforst-Collins et al., 1997). A previous study had demonstrated that rabbits receiving oral doses of CI-1017
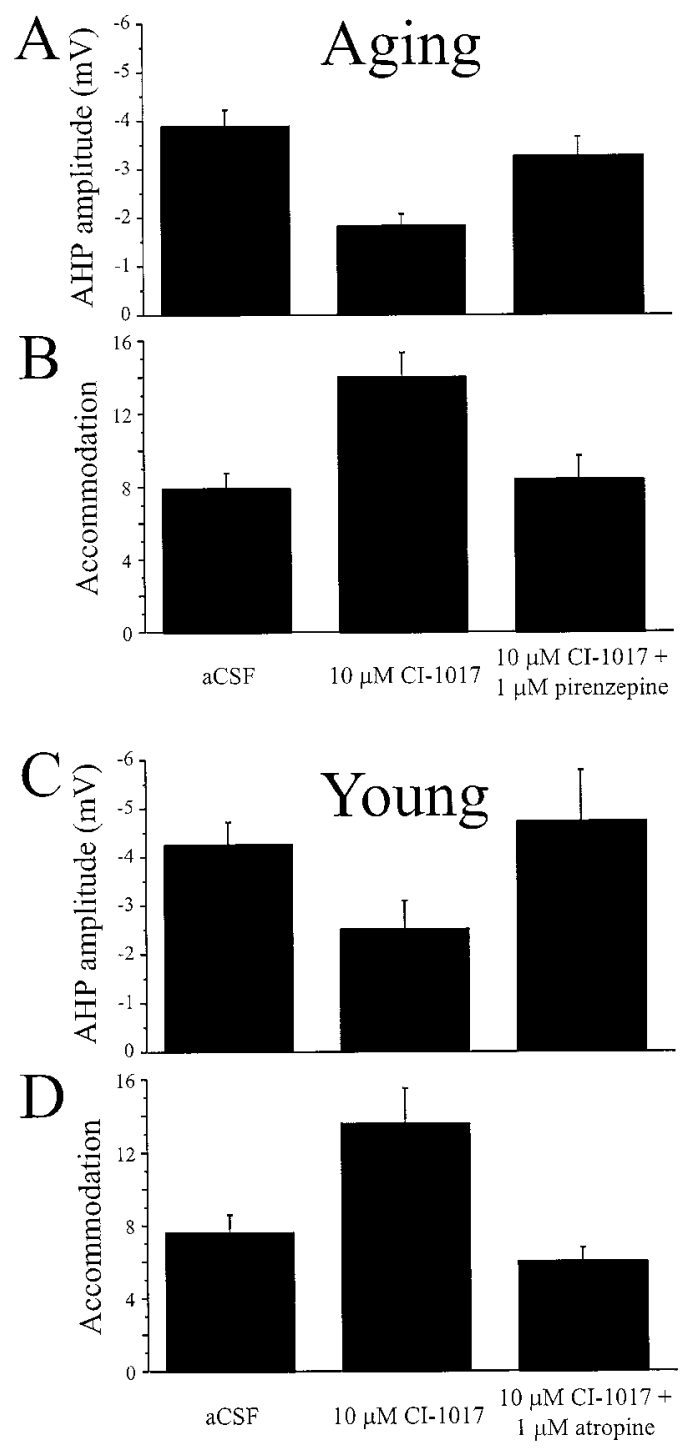

Figure 4. CI-1017 increased the excitability of both young and aging hippocampal pyramidal neurons by significantly reducing the amplitude of the AHP and spike-frequency adaptation. A, CI-1017 $(10 \mu \mathrm{M})$ significantly reduced the mean amplitude of the AHP in neurons from aging rabbits, and the effect was significantly reversed after application of the $\mathrm{m} 1$ specific antagonist pirenzepine $(1 \mu \mathrm{M}) . B$, CI-1017 significantly reduced the spike-frequency adaptation of neurons from aging rabbits after application of the drug $(10 \mu \mathrm{M})$ to the bath; the effect was significantly reversed by the addition of pirenzepine $(1 \mu \mathrm{M}) . C, \mathrm{CI}-1017(10 \mu \mathrm{M})$ reduced the mean amplitude of the AHP in neurons from young rabbits; the effect was reversed after application of the cholinergic antagonist atropine $(1 \mu \mathrm{M})$. $D$, CI-1017 (10 $\mu \mathrm{M})$ significantly reduced the spike-frequency adaptation of neurons from young rabbits; the effect was significantly reversed by the addition of atropine $(1 \mu \mathrm{M})$.

(Kronforst-Collins, 1998) did not exhibit a significant increase in CRs relative to controls. Thus, oral administration of the drug appears not to be ideal in rabbits.

The amplitude of the UR was found to increase during paired trials across sessions. This was likely to be due to either increased reflex facilitation produced by the combined presentation of the CS and US as the CS gained increased salience across training sessions (Harvey et al., 1985; Weisz and LoTurco, 1988) or to an increase in the duration of the CRs. We cannot be certain whether either, or both, effects were occurring because neither air 


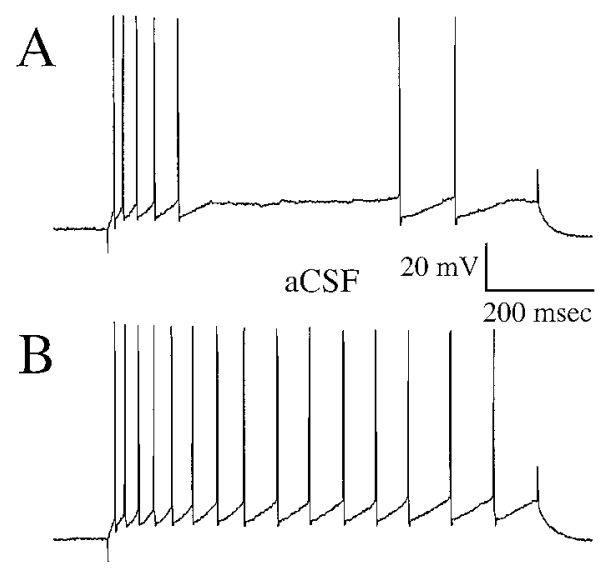

$10 \mu \mathrm{M} \mathrm{CI}-1017$

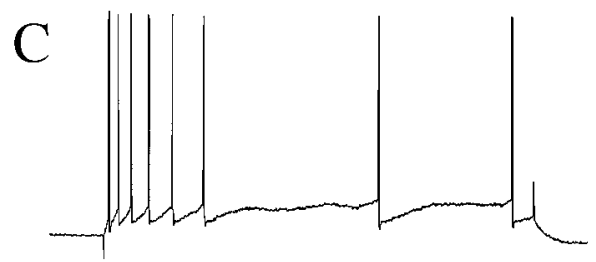

$10 \mu \mathrm{M}$ CI- $1017+1 \mu \mathrm{M}$ atropine

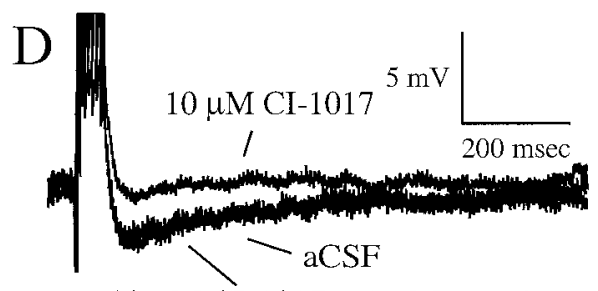

$10 \mu \mathrm{M}$ CI- $1017+1 \mu \mathrm{M}$ atropine

Figure 5. Typical examples of the effects of CI-1017 on biophysical properties from a single hippocampal CA1 pyramidal neuron from a young naive rabbit. An $800 \mathrm{msec}$ pulse was used to examine accommodation after a burst of four action potentials. $A$, Accommodation of the neuron in aCSF. $B$, Accommodation is reduced by the addition of CI1017, i.e., the cell is more excitable. $C$, The excitability change due to CI-1017 is reversed by the addition of the muscarinic antagonist atropine. $D$, Examples of the postburst AHP during control (aCSF), drug (CI1017), and reversal (CI-1017 plus atropine) conditions.

puff alone trials nor tone alone trials were presented during the daily sessions. However, the results from air puff alone trials presented on the last day of training indicated that there was no significant effect of the drug on the UR. This, and the lack of pseudoconditioning, suggests that direct activation of the UR pathway was not significantly contributing to the increase in CRs.

The effects of CI-1017 should be generalized to other learning paradigms if it is acting at $\mathrm{M} 1 / \mathrm{m} 1$ cholinergic synapses throughout the brain. CI-1017 has in fact been shown to improve learning in other tasks in rodents and nonhuman primates. At an oral dose of $1.0 \mathrm{mg} / \mathrm{kg}$ (p.o.), it significantly shortened the latency of $\mathrm{C} 57 \mathrm{BL} / 10 \mathrm{SnJ}$ mice to find a hidden platform in the Morris water maze (Symons et al., 1988; Schwarz et al., 1997). These mice have small hippocampi and decreased numbers of pyramidal neurons. The drug (0.1 mg/kg, p.o.) also improved water maze performance in rats with ibotenic acid lesions of forebrain cholinergic neurons when compared with sham-lesioned controls, and it improved the performance of adult rhesus monkeys $(0.32 \mathrm{mg} / \mathrm{kg}$, i.m.) on a continuous performance task after the administration of scopolamine (Schwarz et al., 1997). Another M1 agonist, AF102B, has also been shown to be effective in a single-blind placebo-controlled study using patients with probable AD (Fisher et al., 1996).

In contrast to the facilitating effects of CI-1017 on learning, the M1 antagonist pirenzepine has been shown to have disruptive effects. It was found to impair acquisition of inhibitory avoidance in mice (Caufield et al., 1983), increase the water maze escape latency in rats after intracerebroventricular injections (Hagan et al., 1987; Hunter and Roberts, 1988), disrupt representational memory in rats (Messer and Hoss, 1987; Messer et al., 1987, 1990), and impair working memory in rats given $1 \mu \mathrm{g} / \mathrm{side}$ intrahippocampally (Ohno et al., 1994). Pirenzepine was also very effective in blocking the effects of CI-1017 on the AHP and spike-frequency accommodation of hippocampal pyramidal neurons.

The mechanism of action for CI-1017 is believed to involve $\mathrm{M} 1 / \mathrm{m} 1$ receptors at central cholinergic synapses, particularly within the cortex and hippocampus. This was directly tested here by making intracellular recordings from CA1 pyramidal neurons in hippocampal slices from young and aging naive rabbits. The results indicate that CI-1017 significantly increased the excitability of CA1 hippocampal neurons, i.e., it reduced spike-frequency adaptation and the postburst AHP. The effect was very robust at a concentration of $10 \mu \mathrm{M}$ and reached statistical significance when evaluated in relatively few cells. The effect was present but less pronounced at a concentration of $1 \mu \mathrm{M}$ (data not shown), and it was reversed by the addition of atropine or pirenzepine to $10 \mu \mathrm{M}$ CI-1017, indicating the expected muscarinic mode of action.

Several in vitro experiments have demonstrated that application of ACh, muscarinic agonists, or anticholinesterases increase neuronal excitability (reduced AHP and accommodation) of hippocampal pyramidal neurons (Benardo and Prince, 1981, 1982; Cole and Nicoll, 1983, 1984a,b; Madison and Nicoll, 1984; Halliwell, 1990; Pedarzani and Storm, 1996; Oh et al., 1999). Furthermore, both the AHP and accommodation were reduced in CA1 neurons from young and aging rabbits that acquired eyeblink conditioning but not in trained rabbits that did not learn (Disterhoft et al., 1986, 1988, 1996b; Coulter et al., 1989; de Jonge et al., 1990; Moyer et al., 1992, 1996; Thompson et al., 1996b). Both the AHP and accommodation are greater in CA1 neurons from aging rabbits (Moyer et al., 1992; Oh et al., 1999) and rats (Landfield and Pitler, 1984; Potier et al., 1992) compared with those from young animals. We have shown previously that two drugs that increase conditioning rate in aging rabbits, nimodipine (Deyo et al., 1989; Kowalska and Disterhoft, 1994) and metrifonate (Kronforst-Collins et al., 1997), both enhance CA1 neuronal excitability when applied in vitro (Moyer et al., 1992; Oh et al., 1999). These findings, along with those summarized here, suggest that aging rabbits may learn better if hippocampal neuronal excitability is enhanced to become similar to that of neurons from young rabbits as a result of drug application.

Although metrifonate (a cholinesterase inhibitor) and CI-1017 (an M1 agonist) produced similar results during eyeblink conditioning in aging rabbits, the mechanism of action for CI-1017 appears theoretically more favorable for the treatment of AD because of its specificity for M1 receptors. The secondary consequences of activating $\mathrm{m} 1$ and $\mathrm{m} 3$ receptors are also more positive in light of the relationship of $\beta$ amyloid deposition and AD (Robinson and Harrell, 1997), i.e., activation of cell surface receptors that are positively coupled to phospholipase C, including $\mathrm{m} 1$ and $\mathrm{m} 3$, results in increased release of soluble amyloid 
precursor protein (Nitsch et al., 1992; Hung et al., 1993) and a reduction in $\beta$ amyloid peptide observed in vitro (Buxbaum et al., 1992; Nitsch et al., 1992; Hung et al., 1993). This suggests that, in addition to alleviating cognitive symptoms of the disease, $\mathrm{m} 1$ receptor activation may interfere with $\beta$ amyloid formation, the ratio of soluble to amyloidogenic fragments produced in the brain, and slow the disease process itself.

\section{REFERENCES}

Akase E, Thompson LT, Disterhoft JF (1994) A system for quantitative analysis of associative learning. II. Real-time software for MS-DOS microcomputers. J Neurosci Methods 54:119-130.

Bartus RT, Dean RL, Beer B, Lippa S (1982) The cholinergic hypothesis of geriatric memory dysfunction. Science 217:408-416.

Benardo LS, Prince DA (1981) Acetylcholine induced modulation of hippocampal pyramidal neurons. Brain Res 211:227-234.

Benardo LS, Prince DA (1982) Cholinergic excitation of mammalian hippocampal pyramidal cells. Brain Res 249:315-331.

Bonner TI, Buckley NJ, Young AC, Brann MR (1987) Identification of a family of muscarinic acetylcholine receptor genes. Science 237:527-532.

Buxbaum JD, Oishi M, Chen HI, Pinkas-Kramarski R, Jaffe EA, Gandy SE, Greengard P (1992) Cholinergic agonists and interleukin 1 regulate processing and secretion of the Alzheimer beta/A4 amyloid protein precursor. Proc Natl Acad Sci USA 89:10075-10078.

Bymaster FP, Heath I, Hendrix JC, Shannon HE (1993) Comparative behavioral and neurochemical activities of cholinergic antagonists in rats. J Pharmacol Exp Ther 267:16-24.

Caulfield MP, Higgins GA, Straughan DW (1983) Central administration of the muscarinic receptor subtype-selective antagonist pirenzepine selectively impairs passive avoidance learning in the mouse. J Pharm Pharmacol 35:131-132.

Cole AE, Nicoll RA (1983) Acetylcholine mediates a slow synaptic potential in hippocampal pyramidal cells. Science 221:1299-1301.

Cole AE, Nicoll RA (1984a) Characterization of a slow cholinergic post-synaptic potential recorded in vitro from rat hippocampal pyramidal cells. J Physiol (Lond) 352:173-188.

Cole AE, Nicoll RA (1984b) The pharmacology of cholinergic excitatory responses in hippocampal pyramidal cells. Brain Res 305:283-290.

Coulter DA, LoTurco JJ, Kubota M, Disterhoft JF, Moore JW, Alkon DL (1989) Classical conditioning reduces amplitude and duration of calcium-dependent afterhyperpolarization in rabbit hippocampal pyramidal cells. J Neurophysiol 61:971-981.

de Jonge MC, Black J, Deyo RA, Disterhoft JF (1990) Learninginduced afterhyperpolarization reductions in hippocampus are specific for cell type and potassium conductance. Exp Brain Res 80:456-462.

Deyo RA, Straube K, Disterhoft JF (1989) Nimodipine facilitates trace conditioning of the eye-blink response in aging rabbits. Science 243:809-811.

Disterhoft JF, Kwan HH, Lo WD (1977) Nictitating membrane conditioning to tone in the immobilized albino rabbit. Brain Res 137:127-143.

Disterhoft JF, Coulter DA, Alkon DL (1986) Conditioning-specific membrane changes of rabbit hippocampal neurons measured in vitro. Proc Natl Acad Sci USA 83:2733-2737.

Disterhoft JF, Golden DT, Read HL, Coulter DA, Alkon DL (1988) AHP reductions in rabbit hippocampal neurons during conditioning correlate with acquisition of the learned response. Brain Res 462:118-125.

Disterhoft JF, Thompson LT, Weiss C, Moyer Jr JR, Van der Zee E, Carrillo MC, Kronforst-Collins M, Power J (1995) The calcium hypothesis for Alzheimer's disease: insights from animal and human studies. Neurosci Res Commun 17:121-131.

Disterhoft JF, Carrillo MC, Hopkins RO, Gabrieli JDE, Kesner RP, (1996a) Impaired trace eyeblink conditioning in severe medial temporal lobe amnesics. Soc Neurosci Abstr 22:1866.

Disterhoft JF, Thompson LT, Moyer Jr JR, Mogul DJ (1996b) Calciumdependent afterhyperpolarization and learning in young and aging hippocampus. Life Sci 59:413-420.

Ferrari-DiLeo G, Mash DC, Flynn DD (1995) Attenuation of muscarinic receptor-G-protein interaction in Alzheimer disease. Mol Chem Neuropathol 24:69-91.

Fisher A, Heldman E, Gurwitz D, Haring R, Karton Y, Meshulam H, Pittel Z, Marciano D, Brandeis R, Sadot E, Barg Y, Pinkas-Kramarski
R, Vogel Z, Ginzburg I, Treves TA, Verchovsky R, Klimowsky S, Korczyn AD (1996) M1 agonists for the treatment of Alzheimer's disease. Novel properties and clinical update. Ann NY Acad Sci 777:189-196.

Flynn DD, Ferrari-DiLeo G, Mash DC, Levey AI (1995) Differential regulation of molecular subtypes of muscarinic receptors in Alzheimer's disease. J Neurochem 64:1888-1891.

Geula C, Mesulam M-M (1994) Cholinergic systems and related neuropathological predilection patterns in Alzheimer disease. In: Alzheimer disease (Terry RD, Katzman R, and Bick KL, eds). New York: Raven.

Hagan JJ, Jansen JH, Broekkamp CL (1987) Blockade of spatial learning by the M1 muscarinic antagonist pirenzepine. Psychopharmacology 93:470-476.

Halliwell JV (1990) Physiological mechanisms of cholinergic action in the hippocampus. Prog Brain Res 84:255-272.

Harvey JA, Gormezano I, Cool-Hauser VA (1985) Relationship between heterosynaptic reflex facilitation and acquisition of the nictitating membrane response in control and scopolamine-injected rabbits. J Neurosci 5:596-602.

Hulme EC, Birdsall NJ, Buckley NJ (1990) Muscarinic receptor subtypes. Ann Rev Pharmacol Toxicol 30:633-673.

Hung AY, Haass C, Nitsch RM, Qiu WQ, Citron M, Wurtman RJ, Growdon JH, Selkoe DJ (1993) Activation of protein kinase C inhibits cellular production of the amyloid beta-protein. J Biol Chem 268:22959-22962.

Hunter AJ, Roberts FF (1988) The effect of pirenzepine on spatial learning in the Morris water maze. Pharmacol Biochem Behav 30:519-523.

Jaen J, Barrett S, Brann M, Callahan M, Davis R, Doyle P, Eubanks D,. Lauffer D, Lauffer L, Lipinski W, Moreland D, Nelson C, Raby C, Schwarz R, Spencer C, Tecle H (1995) In vitro and in vivo evaluation of the subtype-selective muscarinic agonist PD 151832. Life Sci $56: 845-852$.

Kaneko T, Thompson RF (1997) Disruption of trace conditioning of the nictitating membrane response in rabbits by central cholinergic blockade. Psychopharmacology 131:161-166.

Kim JJ, Clark RE, Thompson RF (1995) Hippocampectomy impairs the memory of recently, but not remotely, acquired trace eyeblink conditioned responses. Behav Neurosci 109:195-203.

Kowalska M, Disterhoft JF (1994) Relation of nimodipine dose and serum concentration to learning enhancement in aging rabbits. Exp Neurol 127:159-166.

Kronforst-Collins MA (1998) Limbic, cortical, and cholinergic systems function in rabbit eyeblink conditioning. PhD thesis, Northwestern University.

Kronforst-Collins MA, Moriearty PL, Schmidt B, Disterhoft JF (1997) Metrifonate improves associative learning and retention in aging rabbits. Behav Neurosci 111:1031-1040.

Landfield PW, Pitler TA (1984) Prolonged $\mathrm{Ca}^{2+}$-dependent afterhyperpolarizations in hippocampal neurons of aged rats. Science 226:1089-1092.

Levey AI (1996) Muscarinic acetylcholine receptor expression in memory circuits: Implications for treatment of Alzheimer disease. Proc Natl Acad Sci USA 93:13541-13546.

Madison DV, Nicoll RA (1984) Control of the repetitive discharge of rat CA1 pyramidal neurones in vitro. J Physiol (Lond) 354:319-331.

Martin GK, Lonsbury-Martin BL, Kimm J (1980) A rabbit preparation for neuro-behavioral auditory research. Hear Res 2:65-78.

Mash DC, Flynn DD, Potter LT (1985) Loss of M2 muscarine receptors in the cerebral cortex in Alzheimer's disease and experimental cholinergic denervation. Science 228:1115-1117.

McGlinchey-Berroth R, Carrillo MC, Gabrieli JDE, Brawn CM, Disterhoft JF (1997) Impaired trace eyeblink conditioning in bilateral medial temporal lobe amnesia. Behav Neurosci 111:873-882.

Messer Jr WS, Hoss W (1987) Selectivity of pirenzepine in the central nervous system. I. Direct autoradiographic comparison of the regional distribution of pirenzepine and carbamylcholine binding sites. Brain Res 407:27-36.

Messer Jr WS, Thomas GJ, Hoss W (1987) Selectivity of pirenzepine in the central nervous system. II. Differential effects of pirenzepine and scopolamine on performance of a representational memory task. Brain Res 407:37-45.

Messer Jr WS, Bohnett M, Stibbe J (1990) Evidence for a preferential involvement of M1 muscarinic receptors in representational memory. Neurosci Lett 116:184-189. 
Moyer Jr JR, Deyo RA, Disterhoft JF (1990) Hippocampectomy disrupts trace eye-blink conditioning in rabbits. Behav Neurosci 104:243-252.

Moyer Jr JR, Thompson LT, Black JP, Disterhoft JF (1992) Nimodipine increases excitability of rabbit CA1 pyramidal neurons in an age- and concentration-dependent manner. J Neurophysiol 68:2100-2109.

Moyer Jr JR, Thompson LT, Disterhoft JF (1996) Trace eyeblink conditioning increases CA1 excitability in a transient and learning-specific manner. J Neurosci 16:5536-5546.

Nitsch RM, Slack BE, Wurtman RJ, Growdon JH (1992) Release of Alzheimer amyloid precursor derivatives stimulated by activation of muscarinic acetylcholine receptors. Science 258:304-307.

Oh MM, Power JM, Thompson LT, Moriarty P, Disterhoft JF (1999) Metrifonate increases neuronal excitability in CA1 pyramidal neurons from both young and aging rabbit hippocampus. J Neurosci 19:1814-1823.

Ohno M, Yamamoto T, Watanabe S (1994) Blockade of hippocampal M1 muscarinic receptors impairs working memory performance of rats. Brain Res 650:260-266.

Pearce BD, Potter LT (1991) Coupling of $\mathrm{m} 1$ muscarinic receptors to G protein in Alzheimer disease. Alzheimer Dis Assoc Disord 5:163-172.

Pedarzani P, Storm JF (1996) Evidence that Ca/calmodulin-dependent protein kinase mediates the modulation of the $\mathrm{Ca}^{2+}$-dependent $\mathrm{K}^{+}$ current, $\mathrm{I}_{\mathrm{AHP}}$, by acetylcholine, but not by glutamate, in hippocampal neurons. Pflügers Arch 431:723-728.

Perry EK, Tomlinson BE, Blessed G, Bergmann K, Gibson PH, Perry RH (1978) Correlation of cholinergic abnormalities with senile plaques and mental test scores in senile dementia. Br Med J 2:1457-1459.

Potier B, Rascol O, Jazat F, Lamour Y, Dutar P (1992) Alterations in the properties of hippocampal pyramidal neurons in the aged rat. Neuroscience 48:793-806.

Robinson MR, Harrell LE (1997) Cholinergic activity and amyloid precursor protein metabolism. Brain Res Rev 25:50-69.

Schwarz RD, Callahan MJ, Davis RE, Jaen JC, Tecle H (1997) Development of M1 subtype selective muscarinic agonists for Alzheimer's disease: translation of in vitro selectivity into in vivo efficacy. Drug Dev Res 40:133-143.

Solomon PR, Vander Schaaf ER, Thompson RF, Weisz DJ (1986) Hippocampus and trace conditioning of the rabbit's classically conditioned nictitating membrane response. Behav Neurosci 100:729-744.

Solomon PR, Levine E, Bein T, Pendlebury WW (1991) Disruption of classical conditioning in patients with Alzheimer's disease. Neurobiol Aging 12:283-287.
Solomon PR, Brett M, Groccia-Ellison ME, Oyler C, Tomasi M, Pendlebury WW (1995) Classical conditioning in patients with Alzheimer's disease: a multiday study. Psychol Aging 10:248-254.

Symons JP, Davis, RE, Marriott JG (1988) Water maze learning and effects of cholinergic drugs in mouse strains with high and low hippocampal pyramidal cell counts. Life Sci 42:375-383.

Tecle H, Barrett SD, Lauffer DJ, Augelli-Szafran C, Brann MR, Callahan MJ, Caprathe BW, Davis RE, Doyle PD, Eubanks D, Lipiniski W, Mirzadegan T, Moos WH, Moreland DW, Nelson CB, Pavia MR, Raby C, Schwarz RD, Spencer CJ, Thomas AJ, Jaen JC (1998) Design and synthesis of m1-selective muscarinic agonists: $(R)-(-)-(\mathrm{Z})-1-$ azabicyclo[2.2.1] heptan-3-one, $O$-(3-(3'-methoxyphenyl)-2-propynyl) oxime maleate (CI-1017), a functionally m1-selective muscarinic agonist. J Med Chem 41:2524-2536.

Thompson LT, Moyer Jr JR, Akase E, Disterhoft JF (1994) A system for quantitative analysis of associative learning. I. Hardware interfaces with cross-species applications. J Neurosci Methods 54:109-117.

Thompson LT, Moyer Jr JR, Disterhoft JF (1996a) Trace eyeblink conditioning in rabbits demonstrates heterogeneity of learning ability both between and within age groups. Neurobiol Aging 17:619-629.

Thompson LT, Moyer Jr JR, Disterhoft JF (1996b) Transient changes in excitability of rabbit CA3 neurons with a time course appropriate to support memory consolidation. J Neurophysiol 76:1836-1849.

Van der Zee EA, Kronforst-Collins MA, Maizels ET, Hunzicker-Dunn M, Disterhoft JF (1997) gamma Isoform-selective changes in PKC immunoreactivity after trace eyeblink conditioning in the rabbit hippocampus. Hippocampus 7:271-285.

Weisz DJ, LoTurco JJ (1988) Reflex facilitation of the nictitating membrane response remains after cerebellar lesions. Behav Neurosci 102:203-209.

Whitehouse PJ, Au KS (1986) Cholinergic receptors in aging and Alzheimer's disease. Prog Neuropsychopharmacol Biol Psychiatry 10:665-676.

Whitehouse PJ, Struble RG, Clark AW, Price DL (1982) Alzheimer disease: plaques, tangles, and the basal forebrain. Ann Neurol 12:494.

Woodruff-Pak DS, Papka M (1996) Alzheimer's disease and eyeblink conditioning: $750 \mathrm{~ms}$ trace vs. $400 \mathrm{~ms}$ delay paradigm. Neurobiol Aging 17:397-404.

Woodruff-Pak DS, Finkbiner RG, Sasse DK (1990) Eyeblink conditioning discriminates Alzheimer's patients from non-demented aged. NeuroReport 1:45-49. 